\title{
Physical and mechanical characteristics of sustainable self- consolidating concrete incorporating high volume fly ash and cement kiln dust
}

\author{
Mohammed Aldikheeli ${ }^{1, *}$, Shakir Salih', and Faiq Al-Zwainy ${ }^{3}$ \\ ${ }^{1}$ College of Engineering, Kufa University, Najaf, Iraq \\ ${ }^{2}$ Department of Building and Construction Engineering, University of Technology, Baghdad, Iraq \\ ${ }^{3}$ College of Engineering, Al-Nahrain University, Baghdad, Iraq
}

\begin{abstract}
In recent years, sustainable development has become a global issue and several industries (including concrete industry) have made every effort to reduce the high material cost, high energy depletion and $\mathrm{CO}_{2}$ emission in addition to soundly eliminate industrial waste residue. The purpose of this study is to investigate the possibility of production sustainable self-consolidating concrete (SSC) with green materials: Portland limestone cement (PLC), high volume class F fly ash (HVFA) and locally available cement kiln dust (CKD) depending on the limitations of fresh properties that is specified by ACI 273R-07 and EFNARC and to assess the effects of these green materials on the hardened properties. Moreover, microstructure of this concrete was also investigated by means of scanning electron microscopy (SEM). The results displayed that by replacing high levels of cement by type $\mathrm{F}$ fly ash and locally available $\mathrm{CKD}$, it was conceivable to make eco-friendly SCC, satisfying the rheological demands for self-consolidating, with agreeable 28-day compressive

strength.
\end{abstract}

\section{Introduction}

Self-consolidating concrete (SCC) is a very significant advance in the concrete technology in recent times. It is a modern kind of "high performance concrete" with the capability of flowing under its self-weight and without the necessity of vibrations [1]. A better working environment can be provided by using SCC by removing the vibration noise, so it can be contributed for the constructions' sustainability [2]. Civil engineering meeting one fundamental challenge that is to perform projects in harmony with nature using the impression of sustainable development. The concrete industry may be considered to be unsustainable due to the huge production and consumption cycles of concrete have substantial environmental influences [3]. Every year the production of Portland cement is the reason for about 7\% of carbon dioxide $\left(\mathrm{CO}_{2}\right)$ releases in addition to further detrimental emissions such as cement kiln dust. Generality of these emissions are imputed to the clinker production of Portland cement $[4,13]$. The industry has transferred to blended cement in order to reduce the dangerous effects of cement production, where in this cement part of the clinker is replaced for other materials such as ground granulated blast furnace slag, fly ash, natural and industrial pozzolana or limestone [5, 14]. Many standard around the world were standardized the blended cements such as (ASTM C 595-12 [6], EN 1971 [7] and CSA A3001-08 [8]). To get better concrete sustainability and even to attain green or ecological concrete various separate strategies or in combination have been followed [9]. One way is the use of Portlandlimestone cement (PLC) where it has a smaller carbon footprint [10].

Both technical and economical benefits can be achieved by using Portland-limestone cements. It is foreseeable that the production of Portland-limestone cement around the world in the future will be constantly increased [11]. Another way to improve concrete sustainability is by using an increased ratio of supplementary cementing materials (SCMs) (such as silica fume, fly ash, slag and natural pozzolan) or byproduct materials. Energy saving, environment protection and natural resources conservation can be obtained by using SCMs and other alternative/waste materials in concrete [12]. In this research the byproduct materials used were fly ash with high volume fraction and Iraqi cement kiln dust (CKD). The costs due to the production and removal of kiln dust raised up and due to these high costs in addition to future storage space problems, and environmental concerns, the reduction and use of kiln dust has become an important effort.

\section{Research significance}

To produce high volume cement past that required in SCC, high cement content is wanted $\left(450-600 \mathrm{~kg} / \mathrm{m}^{3}\right)$ $[15,16]$ which is not desired neither technically nor

\footnotetext{
"Corresponding author: mohammedr.aldikheeli@uokufa.edu.iq
} 
economically/environmentally. The hope is to make the construction industry proceed toward the sustainability concept and to satisfy this hope the substituting additives such as filling materials and mineral admixtures can be used, especially in SCC [20]. The study of "green", "sustainable" or "eco-efficient" concrete has advanced rising attention among the major contemporary publications about concrete because the affairs concerning the industrial wastes recycling, durability of concrete, environment and the cost will place a pressure on the employment of waste materials [17]. The current study aims at highlighting the possibility to produce sustainable self-consolidating concrete (SSC) with green materials: Portland limestone cement (PLC), high volume class F fly ash (HVFA) and locally available cement kiln dust (CKD) and to evaluate hardened characteristics of SCC produced with these materials.

\section{Materials and experimental program}

\subsection{Materials}

\subsubsection{Cement}

In the present study, the cement used was local Portlandlime stone cement (PLC) available in the markets, Karasta CEM II/A-L $42.5 \mathrm{R}$, produced by Lafarge Company in $\mathrm{Al}$ - Sulaymaniyah city in Iraq. It complies with European Standard EN 197-1 [7] and Iraqi industrial license No: 3868. The physical and chemical characteristics of cement used in this study are presented in Table (1).

\subsubsection{Fine and coarse aggregate}

As fine aggregate natural sand brought from Al-Najaf quarry was used in this work. The grading, physical and chemical properties of the sand used are shown in Table (2). It has a fineness modulus of 2.5 and within the grading zone 3 . A Crushed gravel with a maximum size of $20 \mathrm{~mm}$ was used as a coarse aggregate, the grading, physical and chemical properties of gavel used are shown in Table (3). Both types of aggregate were conformed to the Iraqi specification No.45 / 1984[23].

\subsubsection{Chemical admixture}

A high performance superplasticizer based on modified polycarboxylic ether which is commercially famous (GLENIUM 54) was used, for the liquefaction of the concrete mixtures to achieve the desired workability, throughout this study as a "high range water reducing admixture" (HRWRA). It complies with ASTM C494 [24]. Typical addition proportions were provided by the manufacturer (Basf Chemical Company) as $0.5-2.5$ liters per $100 \mathrm{~kg}$ of cement (cementitious material).

\subsubsection{Fly ash}

Fly ash is generally captured from the chimneys of electric power generation facilities. Fly ash used in present study was obtained from Turkey. The physical and chemical properties of fly ash as provided by the manufacturer are tabulated in Table (4). It can be seen from Table (4) that the fly ash used is considered as class F fly ash as per ASTM C618 standard [25]. As shown in Fig. (1), Pozzolanic Activity Index (PAI) test was conducted on the fly ash used and it was $85 \%$.

\subsubsection{Cement kiln dust}

Cement kiln dust (CKD) is a by-product of cement production. CKD is a fine-grained, particulate material easily entrained in the combustion gases moving through the kiln [18]. The chemical composition of cement kiln dust differs from one cement plant to another because it depends on many factors, such as the composition of the raw materials, the kiln process incorporated for cement manufacturing, and the fuel used to heat the kiln, while the particle size distribution is determined by the collection method employed. Table (5) indicates the chemical composition and Fig. (2) shows the Scanning Electron Microscopy (SEM) of the cement kiln dust used in this research.

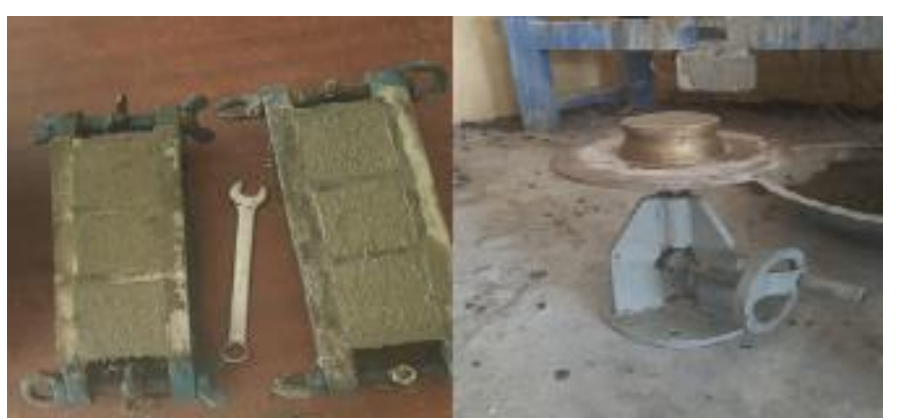

Fig. 1. The pozzolanic activity index (PAI) test.

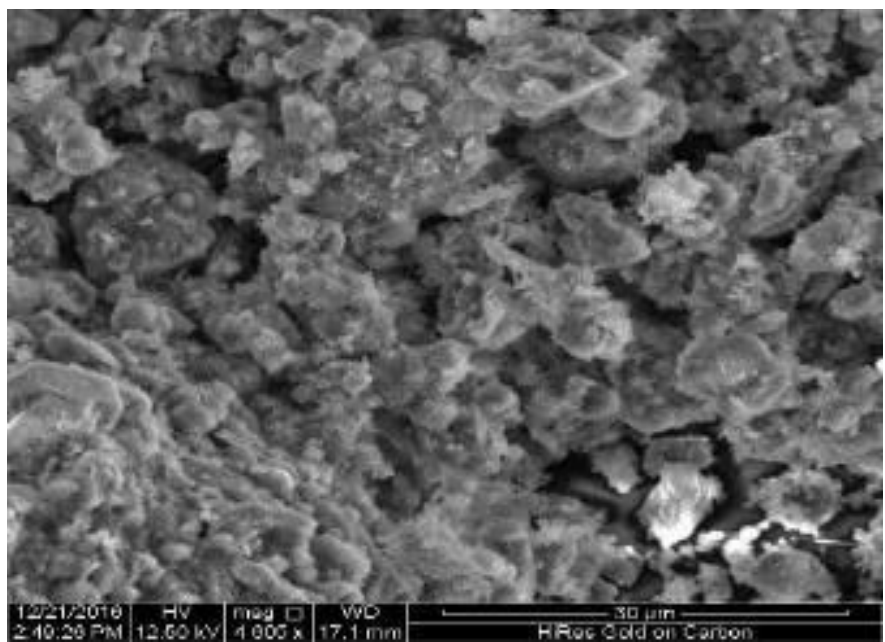


Fig. 2. SEM for CKD used

\subsection{Experimental program}

\subsubsection{Mix proportions}

Because of SCC mixtures highly reliant on the properties and the composition of its ingredients, it can be considered a delicate mix. Two disagreeing properties should be found in each SCC mix, and these are the high flow-ability and the high segregation resistance. For powder type SCC the equilibrium between these two properties can be achieved by the dispersal effect of high-range water-reducing admixture (super-plasticizer) and cohesiveness created by the addition of the filler materials due to the high concentration of fine particles [26]. Yet, there is a continuous improvement in the mix design ways and developing procedures for testing SCC. Mix design criteria are generally concentrated on the mixture proportions and type of the ingredients. One of the chief characteristics in selection the mix proportions of SCC mixtures is the amendment of superplasticizer dosage and the water / powder ratio [26]. In the present work, the reference SCC mixture (REF) was designed according to Okamura and Ouchi [1] taking into account the recommendations of the EFNARC [21] and ACI 237 [22]. The used water/powder ratio (w/p) was kept constant as 0.36 , while the dose of used super-plasticizer was changed to attain the fresh properties that satisfy the limitations of EFNARC [21] and ACI 237 [22], for this, for each mixture several trial batches were produced. Seven different SCC mixes were investigated in this study. One reference concrete mixtures made with 500 $\mathrm{kg} / \mathrm{m}^{3}$ of (PLC) alone (REF), three mixtures had $40 \%$, $50 \%$, and $60 \%$ Class F fly ash that replace cement $(40$, $50,60 \mathrm{FA})$ and two mixtures had a cement replacement of $20 \%$ and $30 \%$ by cement kiln dust (20, 30 CKD). In addition to one binary mixture (50B) had cement replacement of $50 \%$ of the two materials $(20 \%$ CKD plus $30 \%$ FA). Table (6) shows the mixture proportions of these mixes.

\subsubsection{Mixing sequence and samples preparation}

The batching sequence and mixing process impact the consistency of production of SCC. In this study drum type mixer of $0.1 \mathrm{~m}^{3}$ capacity was used to mix the concrete ingredients. The dry constituents of concrete mixes were placed in the mixer such that the cement or (cement plus powder materials) is placed between two layers of sand followed by two layers of gravel, this prevents spillage of cement in air, the dry materials were well mixed for about 3 minutes to attain uniform mix. Then, about $80 \%$ of the required quantity of tap water was added and mixed thoroughly for another 3 minutes. Finally, The HRWR diluted with the residual mixing water was then presented through 30 second, and the concrete was mixed for 2.5 minutes [30]. The concrete stayed at rest in the mixer for 1 minute to permit any big air bubble captured throughout mixing to rise to the surface. The concrete was then remixed for 1 minute [27]. After that the concrete was casted in the moulds without any vibration and instantaneously covered with plastic wrap and kept undisturbed for $24 \mathrm{hr}$. in laboratory circumstances. After $24 \mathrm{hr}$., specimens were removed from the moulds and placed in curing tank until testing.

\subsubsection{Test procedure}

\subsubsection{Tests on fresh SCC}

To calculate and evaluate the fresh features of SCC there are several test methods that had been developed around the world. Among these test methods there is no single test that can be used alone to assess all of the main parameters, so a combination of tests is necessary to totally describe a SCC mix. In this work, the three main characteristics of SCC listed below are performed according to the methods mentioned in EFNARC [21] and/or ACI 237R-07[22]:

i- Filling ability: ability to fill a mould or form under its own weight. This property can be assessed by slumpflow and $\mathrm{T}_{50}$ test. To execute the test, the fresh concrete mix was filled into the slump cone till full and then the slump cone was raised upwards to permit the concrete mix to flow. When the flow ended, two perpendicular diameters of the concrete patty made were measured and averaged as the slump-flow as in Fig. (3-a). While the slump-flow test is carrying out, viscosity is indirectly measured by $\mathrm{T}_{50}$ test. Any sign of segregation was observed, as indicated by the formation of a strip of paste/mortar without coarse aggregate at the edge of the concrete patty.

ii- Passing ability: ability to flow through reinforcing bars or other obstacles without segregation and without mechanical vibration. This property can be assessed by J-ring test. According to ACI 237R-07 [22] the difference between the conventional slump flow value and the J-ring slump flow value is calculated and it is an indication of the degree to which the passage of SCC through reinforcing bars is restricted. According to EFNARC [21] the passing ability can be indicated by measuring the differences in height between the concrete inside and that just outside the J-Ring as shown in Fig. (3-b).

iii-Resistance to segregation: ability of fresh concrete to remain homogenous in composition during transport and placing. This property can be assessed by Column segregation test as shown in Fig. (3-c). This test was done according to ACI 237R-07 [22] and the following equation is used to determine the percent segregation:

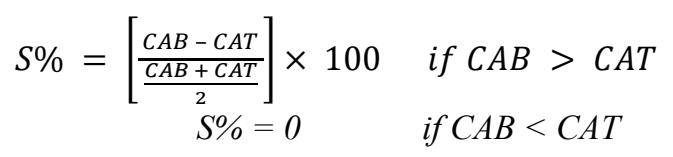

Where: $\mathrm{S}=$ percent segregation; CAT $=$ mass of coarse aggregate in the top section of the column; and $\mathrm{CAB}=$ 
mass of coarse aggregate in the bottom section of the column.

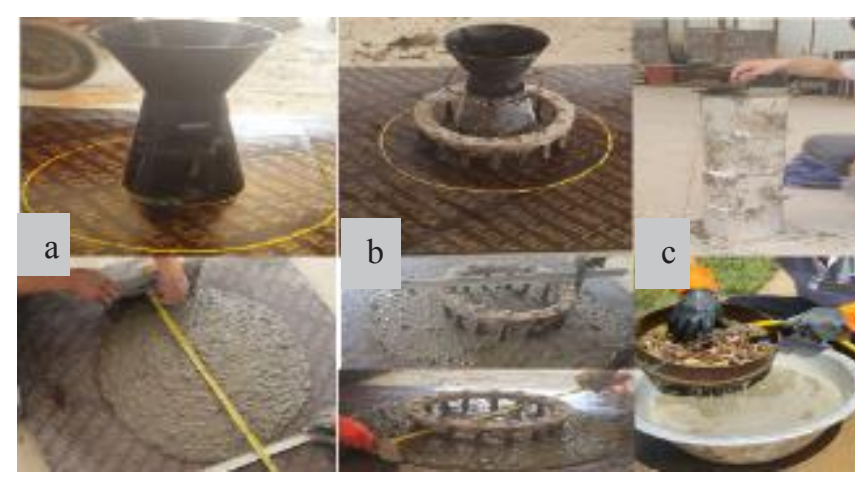

Fig. 3. Tests of fresh (SCC)

\subsubsection{Tests on hardened SCC}

i- Compressive strength test:

Concrete compressive strength test was performed according to the BS EN 12390-3 [28] on $100 \mathrm{~mm}$ cubes, by using ELE digital compression machine of $2000 \mathrm{KN}$ as shown in Fig. (4-a).

\section{ii-Splitting tensile strength test:}

Splitting tensile strength of the concrete was carried out in according to ASTM C496 - 04 [29] on cylinders of $(100 \mathrm{~mm} \times 200 \mathrm{~mm})$ by using the same machine used for testing the compressive strength. The specimen was placed horizontally between the plates of testing machine and the load was increased at a rate of $(0.94$ $\mathrm{KN} / \mathrm{s}$.) until failure by splitting along the vertical axis takes place as shown in Fig. (4-b).

iii-Static modulus of elasticity test:

The static modulus of elasticity was determined according to ASTM C469 - 02 [40] using (d=150 mm, $\mathrm{h}=300 \mathrm{~mm}$ ) cylindrical specimens and mechanical strain gauges (ELE) of effective length equal to $150 \mathrm{~mm}$ as shown in Fig. (4-c). The chord modulus was used in this study and in this modulus, the slope of a line drawn from a point representing $50 \mu €$ to the point corresponding to $40 \%$ of the ultimate stress and it is calculated as follow:

$E c=S 2-S 1 / \epsilon 2-0.00005$

where:

$\mathrm{E}_{\mathrm{c}}=$ chord "Young" modulus of elasticity, (MPa)

$\mathrm{S}_{2}=$ stress corresponding to $40 \%$ of ultimate load, (MPa)

$\mathrm{S}_{1}=$ stress corresponding to a longitudinal strain

(0.00005), (MPa

$\varepsilon_{2}=$ longitudinal strain produced by stress $\mathrm{S}_{2}$

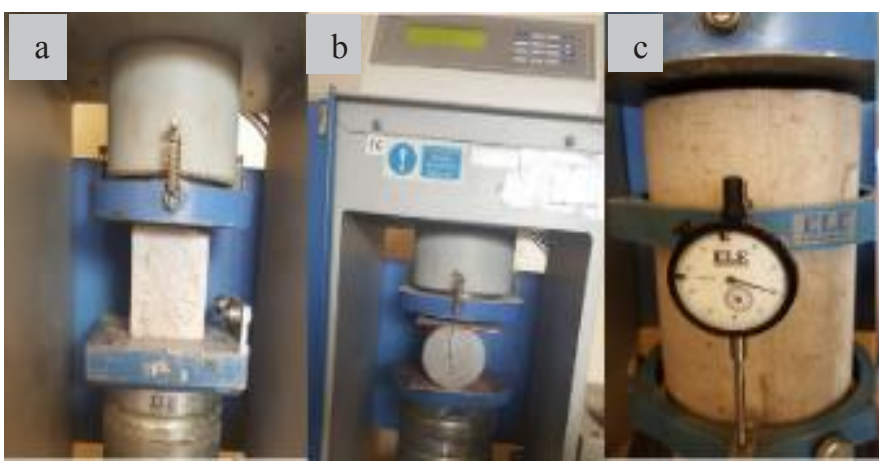

Fig. 4. Tests of hardened SCC

\section{Results and discussion}

\subsection{The effect of replacement level of fly ash and cement kiln dust on the fresh properties of SCC}

According to EFNARC [21] a concrete mixture can only be classified as SCC if the requirements for filling, passing, and segregation resistivity characteristics are fulfilled. Fig. (3) shows the fresh SCC after conducting the slump flow, J-ring (flow and height differences) and column segregation tests. Table (7) presents the fresh properties namely (filling ability, passing ability and segregation resistance) of the studied mixes accompanied by the acceptable criteria proposed by EFNARC [21] and ACI 234R-07[22]. In terms of filling ability, it can be seen from table (7) and Figure (5) that the slump flow diameter $\left(d_{s}\right)$ for all mixtures ranges between (668-752) $\mathrm{mm}$ which is a sign of good deformability conforming to the recommendations of EFNARC [21] (class $\mathrm{SF}_{2}$ ) and ACI [22]. Similarly, the $\mathrm{T}_{50}$ (which may be considered as in direct method to assess plastic viscosity) was always in the range specified (2-5) sec and according to EFNARC [21] all mixes within $\mathrm{VS}_{2}$ class. The slump flow diameter $\left(\mathrm{d}_{\mathrm{s}}\right)$ for SCC with $(40,50,60) \%$ fly ash replacement was $(727$, $740,752) \mathrm{mm}$ with an increase of $(4.4,6.1,8.2) \%$ respectively in comparison to the reference SCC mix though they have lower super-plasticizer dosage. The slump flow diameter $\left(\mathrm{d}_{\mathrm{s}}\right)$ of CKD mixes were lower than that of FA and REF mixes and $\left(\mathrm{d}_{\mathrm{s}}\right)$ reduced as CKD replacement increase. This reduction in filling ability may be imputed to absorbing mixing water by CKD due to the free lime that is found in CKD which rapidly reacts with water in addition to the higher fineness of CKD [19]. In binary mix (50B) which contains CKD together with FA showed better filling and passing abilities than mixes with CKD alone. This can be due to spherical shape of FA particles which induces a ball bearing effect so the poor fresh properties of CKD can be overcome by the incorporation of FA together with CKD to make binary system.

For fly ash series $\left(T_{50}\right)$ increase with the increasing Fly ash content and this is probably because of lower specific gravity of fly ash compared with cement and this will lead to increasing paste volume which results in 
greater plasticity and better cohesiveness [32]. Also for this reason the stability of FA concrete mixtures increases with an increase of the FA ratio used. With respect to the stability the different SCC mixes operate well, as all these mixtures showed a segregation resistance according to ACI 237R [22] less than $10 \mathrm{~mm}$ as shown in Fig. (6).

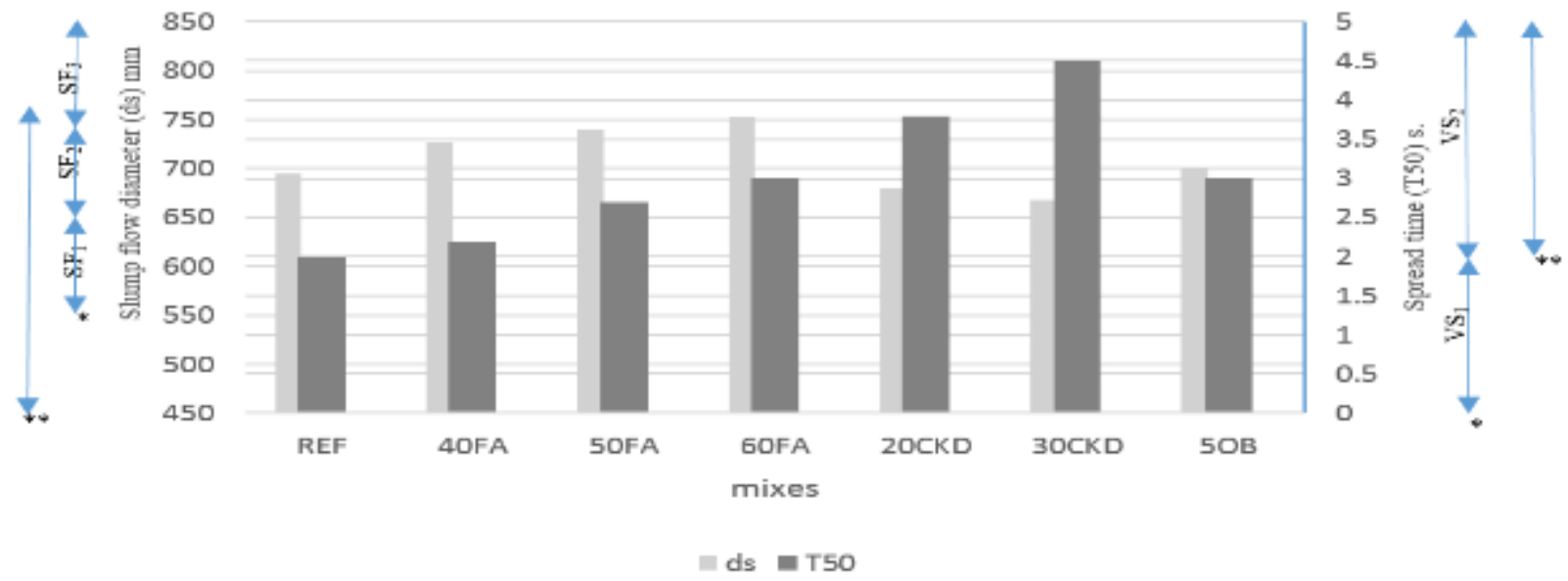

Fig. 5. filling ability for SCC mixes with acceptance criteria of EFNARC* [21] and ACI ** [22].

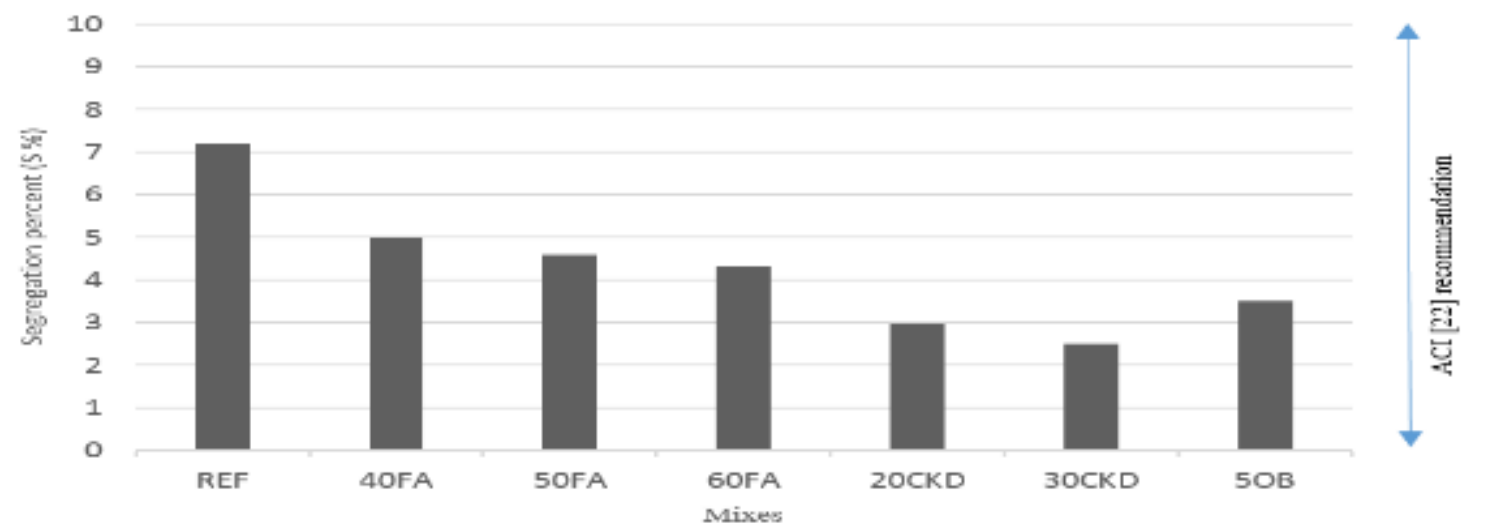

Fig. 6. Segregation resistance (static stability) for SCC mixes with acceptance criteria of ACI237R [22].

In the J-ring test as shown in Fig. (7) and Table (7) all SCC mixes exhibited passing ability in terms of the difference in heights of the concrete inside and outside of the ring according to EFNARC [21] in the range of (2-6.3). Also, it was observed that when passing ability expressed by the difference of values between the slump flow without and with the J-ring according to the ACI 237R [22] $\left(d_{\mathrm{s}}-\mathrm{d}_{\mathrm{J}}\right)$ to be with $(0-25) \mathrm{mm}$ except for 30CKD mix which was around $38 \mathrm{~mm}$ so this mix may exhibit minimal to noticeable blocking and this may be due to the incorporation of high level of CKD, increase in the fines amount of the mix and thus, making the mixture very sticky.

With respect to the dosage of super plasticizer (SP) used, it can be seen from Table (7) that FA mixes consume lower SP dosage compared with CKD mixes and according to Mehta [31] this may be due to three mechanisms. First, the fine fly ash particles prevent cement flocculation thus, the cement particles are dispersed effectively and do not trap large amounts of water. Also, since the fly ash particles have a smooth, spherical surface so that inter-particle friction is reduced. Finally, there is more efficient particle packing within the paste. Moreover, the higher dosage of SP in CKD mixes can be compensated with the incorporation of FA together with CKD as in mix (50B) which had the same SP dosage as $20 \mathrm{CKD}$ mix but with higher slump flow diameter.

From the fresh properties it can be seen that all the SCC mixes had fallen in desired range as per EFNARC[21] and ACI 234R[22] recommendations, so sustainable SCC can be produced by using HVFA and CKD. Hooton et al. [11] stated that the replacement of clinker with limestone filler in the production of blended cement decreases the required amount of water and increases the workability so the significant role of PLC in obtaining these results must be considered. 


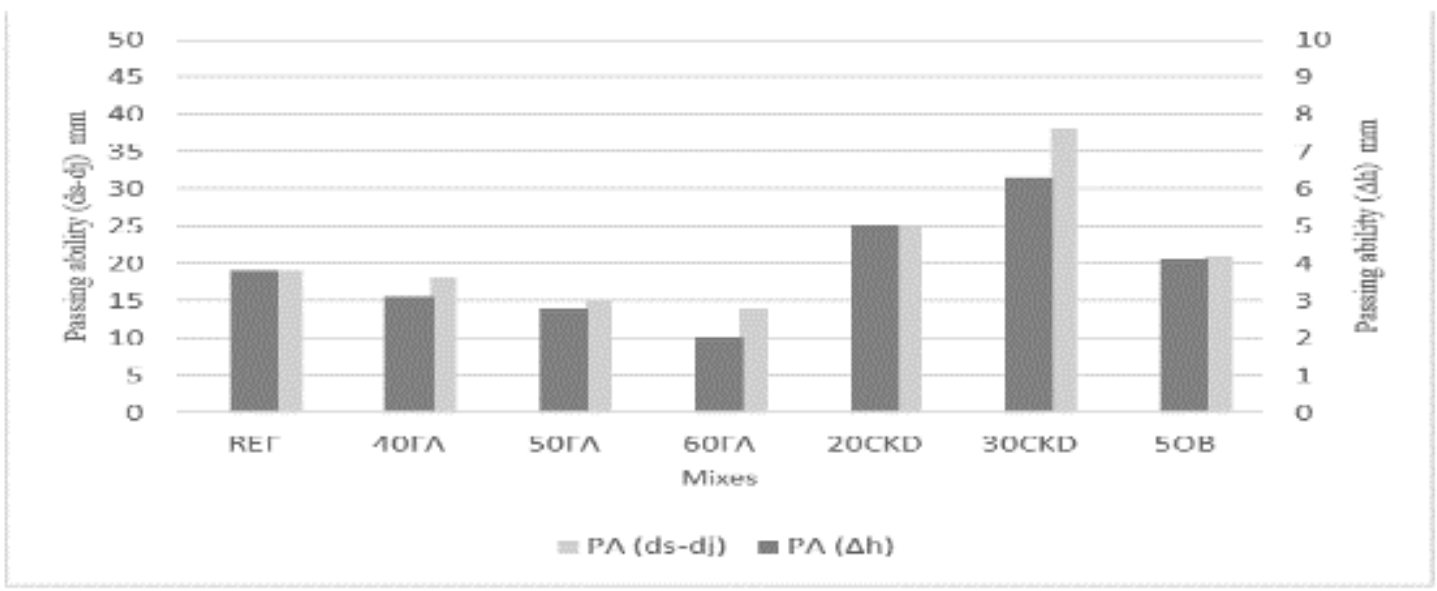

Fig. 7. Passing ability (PA) for SCC mixes according to EFNARC [21] $(\Delta \mathrm{h})$ and according to ACI 237R [22] $\left(\mathrm{d}_{\mathrm{s}}-\mathrm{d}_{\mathrm{j}}\right)$

\subsection{The effect of replacement level of fly ash and cement kiln dust on the hardened properties of SCC}

\subsubsection{Compressive strength}

The average compressive strength of all SCC mixes at 7 , 28, 56 and 90 days are shown in Fig. (8) and Table (8). As the curing time increased the compressive strength of all SCC mixes also increased. The REF SCC mix gives the higher compressive strength compared to other SCC concrete mixes at all ages as shown in Fig. (8) and this may be due to high Portland limestone cement (PLC) used where according to Leemann et al. [33] the concrete that is produced with (PLC) will have a slightly lower interfacial transition zone (ITZ) thickness. This can be interpreted as an effect of grain-size dependent particle packing. Besides, REF mix containing higher superplasticizer (SP) dosage compared to FA mixes and it is generally agreed that when (SP) is used to lower water requirement, an increase in compressive strength will occur.

In terms of FA SCC mixes that contain $(40,50,60)$ $\%$ replacement levels, the results showed that at all test ages, as the fly ash amount increased, the compressive strength of these mixes decreased and it was lower than the REF SCC control mix, especially at early ages as shown in Figure (8). According to Yazici et al. [34] because of the dilution effect in addition to slow pozzolanic reaction of fly ash this reduction in compressive strength occurs in binary blended Portland cement comprising fly ash, but in this study there was a slight reduction in compressive strength at early ages compared to REF mix and this may be due to the use of (PLC) instead of ordinary Portland cement, where Weerdt et al. [35] indicated that when compared to limestone free cements the existence of limestone powder can be led to the creation of hemi- and monocarbonate and to a stabilization of ettringite, where a part of the ettringite (AFt) transformed to monosulphate (AFm). So, an increase in the volume of the hydrates can happen and an increase in compressive strength may occur. This effect was amplified for the fly ash-limestone blended cements due to the additional alumina provided by the fly ash reaction. Thus, the problems of low early compressive strength in addition to demolding problem (due to long setting time) associated with HVFA concrete were overcome in this study.

However, the compressive strength of the binary SCC mix (50B), which contains ( $30 \% \mathrm{FA}+20 \% \mathrm{CKD})$ is still lower than that of the REF control mix and this could be attributed to the dilution effect, which cannot be compensated through pozzolanic reaction of fly ash and micro filler effect of CKD. Though, when compared the (50B) SCC mix with FA and CKD SCC mixes, the results indicate that this mix has higher compressive strength compared to the others as shown in Figure (8) and this may be due to two reasons; the first reason is the remarkable synergistic effect of the pozzolanic reaction by FA and micro filler by CKD (higher packing density). The second reason is the activation of FA by CKD, this activation was also reported by many studies [36, 37] where the calcium hydroxide created through CKD hydration (due to free lime content) and high sulphate content in CKD (which worked as an activator in the existence of alkalis) stimulates the pozzolanic reaction in fly ash containing system and results in the creation of (C-A-S-H).

For FA SCC mixes the compressive strength is higher than that of CKD SCC mixes as shown in Figure (8) and this may be due to the higher amount of alumina that is found in the mixtures that containing fly ash which will cause an increment in $\mathrm{C}_{3} \mathrm{~A}$ amount, moreover, there is an increment in "calcium silicate hydrate (C-S-H)" content that is generated due to the pozzolanic reaction of fly ash [38]. Whereas for CKD SCC mixes the lowering in compressive strength may be attributed to the high amounts of alkalis, chlorides and sulphates, and also due to the dilution effects (due to lowering cement content) which influence the amount of (C-S-H) and aluminate hydrates, leading to the creation of significant amounts of hydrated sulpho-aluminates and chloro-aluminates that aid expansion and softening. 


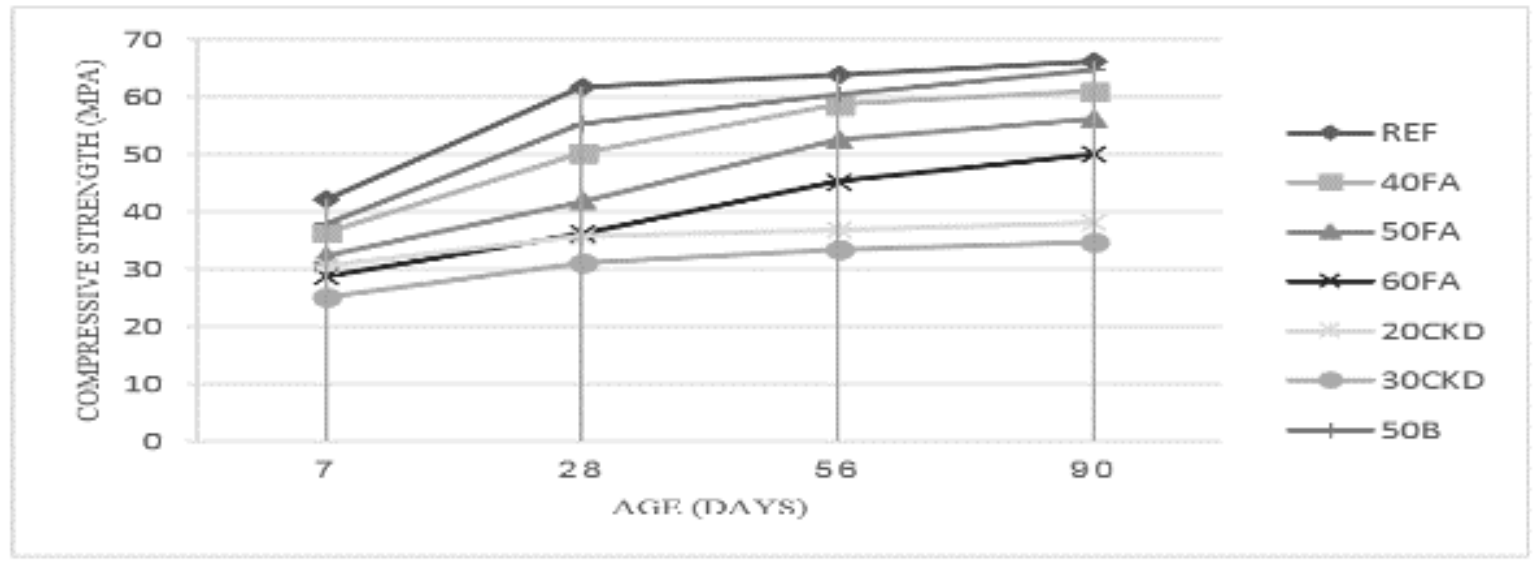

Fig. 8. development of compressive strength for SCC mixes

\subsubsection{Splitting tensile strength}

Broken specimens from split tensile strength test were also used for another assessing the segregation and regularity in the allocation of the aggregates as shown in Fig. (9). The splitting tensile strength governs the cracking behavior and affects other properties such as stiffness and durability of concrete. In this research, the splitting tensile strength was measured at 28 and 90 days and the values for all types of SCC mixes are presented in Table (8) and Fig. (10). The test results showed that in general, all concrete mixes exhibit a continuous increase in the splitting tensile strength from 28 to 90 days. The REF SCC mix showed superior performance in splitting tensile strength compared to other SCC mixes (40, 50, $60) \% \mathrm{FA},(20,30) \% \mathrm{CKD}$ and $50 \mathrm{~B}$ and the percentage increase was $(28.6 \%, 60.2 \%, 80.6 \%, 93.3 \%, 114 \%$ and $15.3 \%)$ at 28 days and $(12.5 \%, 30 \%, 38.5 \%, 80 \%, 111 \%$ and $7.2 \%$ ) at 90 days, respectively as shown in Fig. (10), this may be due to high amounts of cement and superplasticizer used causing an improvement in the interfacial transition zone (ITZ) and enhancing the bond between the aggregate and cement paste.

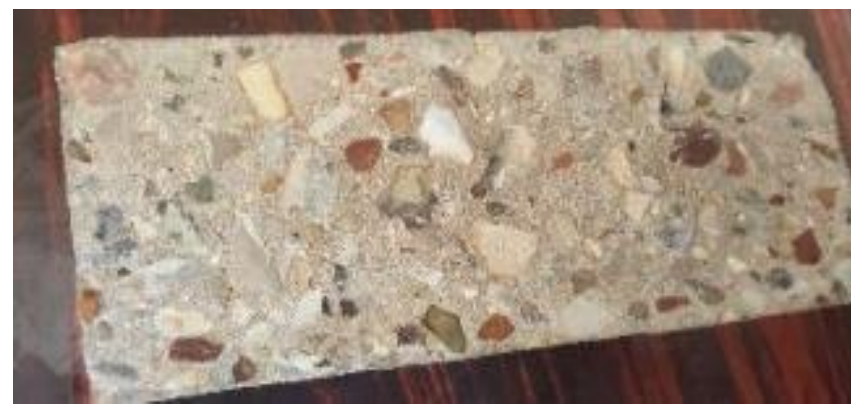

Fig. 9. broken specimen from splitting tensile test.

For FA SCC mixes the results showed that the splitting tensile strength decreased as fly ash content increased in both ages but these mixes exhibit better splitting tensile strength compared with CKD SCC mixes as shown in Fig. (10), this behavior may be attributed to the pozzolanic reaction of fly ash with calcium hydroxide $\mathrm{Ca}(\mathrm{OH})_{2}$ being liberated during the hydration of cement, thus, the capillary voids are reduced in size and dense crystals of $\mathrm{Ca}(\mathrm{OH})_{2}$ are replaced with additional (C-S-H) (the main strengthcontributing compound) of low permeability as a result of that strengthening the "interfacial transition zone" and lowering the micro cracking which causes a significant increase in tensile strength. Whereas the reduction in tensile strength in CKD mixes is due to poor bonding between aggregate and cement paste.

For binary mix (50B) showed superior performance compared to FA and CKD mixes with a very slight reduction compared to REF mix and this may be due to the activation of fly ash by CKD, where a collection of activators for alumina-silicates system such as $\mathrm{CaO}$, $\mathrm{CaSO}_{4}$, and different forms of alkalis) are found in CKD and this will result in a binding system with enhanced mechanical characteristics when used together with fly ash due to the development of ettringite, monosulfate and syngenite phases in addition to the (C-S-H) formation [37]. So all these products in addition to the process of pore-size and grain size refinement greatly reduced the porosity in the (ITZ) zone thus, reducing the micro-cracking and improving the splitting tensile strength.

\subsubsection{Modulus of elasticity}

Table (8) shows that the average values of elastic modulus range between (27.4 to 38.24) GPa and (29.6 to 41.25) $\mathrm{GPa}$ at 28 and 90 days respectively. It is clear from Fig. (11) that the modulus of elasticity of the mixes produced increased with age and decreased with higher replacement level. The results indicated that the modulus of elasticity for FA mixes at 28 days decreased when FA content in the mixture increased whilst at 90 days there was not a significant difference among these mixes. The increment in the modulus of elasticity at later ages for FA mixes can be attributed to the densification of the paste structure due to the pozzolanic action in addition to improvement in the bond between the aggregate particles and the paste. 


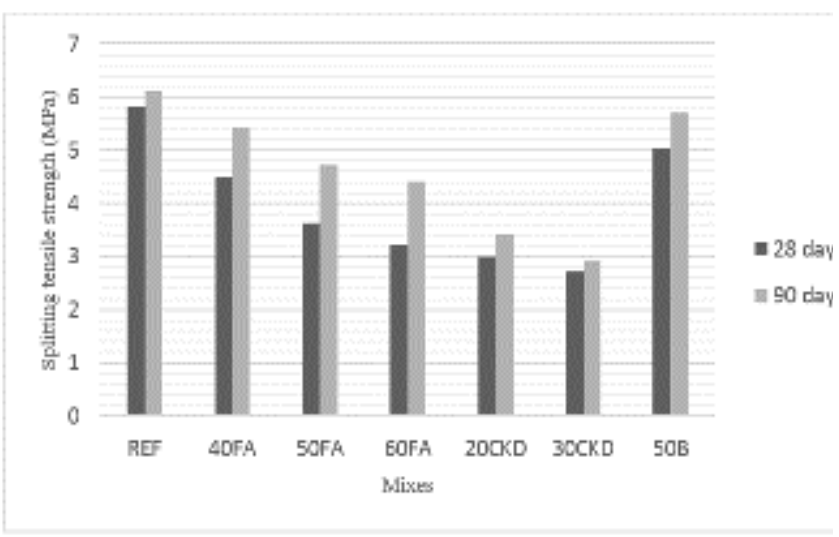

Fig. 10. splitting tensile strength for SCC mixes.

For binary mix $(50 \mathrm{~B})$ the percentage increase in modulus of elasticity compared to FA mixes were (13.8, $21,34) \%$ and $(16,17.5,20.5) \%$ at 28 and 90 days, respectively. This may be explained with the effect of the un-reacted fly ash particles in FA mixes while these particles were activated by CKD when used together in binary mix (50B) so the number of these particles will be reduced and additional hydration products will be formed which will reduce the porosity, especially in the "interfacial transition zone" thus, enhancing the modulus of elasticity.

With respect to the CKD mixes, it showed lower modulus of elasticity compared to other SCC mixes and the modulus of elasticity decreased as CKD increased and this may be due to very high fineness of CKD such that as its content increases, greater shrinkage will occur and thus, a greater number of micro-cracks in the aggregate paste interface will appear that will reduce the modulus of elasticity.

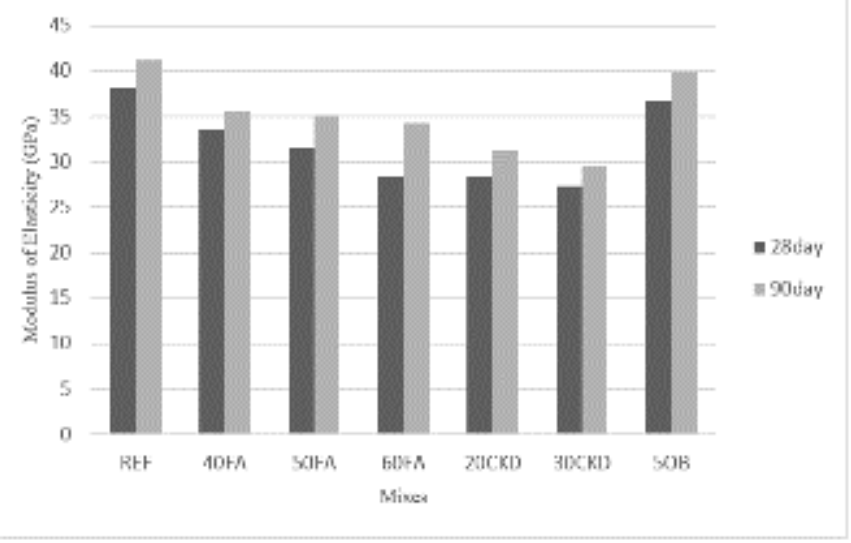

Fig. 11. Modulus of elasticity of SCC mixes.

\subsection{Relationships between hardened properties}

The relationship between the values of splitting tensile strength and modulus of elasticity with the compressive strength for SCC mixes was shown in Fig. $(12,13)$, respectively. Each of these figures, includes equation and correlation coefficient $\left(\mathrm{R}^{2}\right)$ in addition to equations provided by ACI 318[41] and European standard CEB [42] for estimating the splitting tensile strength and modulus of elasticity based on compressive strength for normal strength concrete. The high value of correlation coefficient indicates that the splitting tensile strength and modulus of elasticity have a strong relationship with compressive strength. This relationship looks to be unaffected by the cement replacement nature and content for SCC mixes.

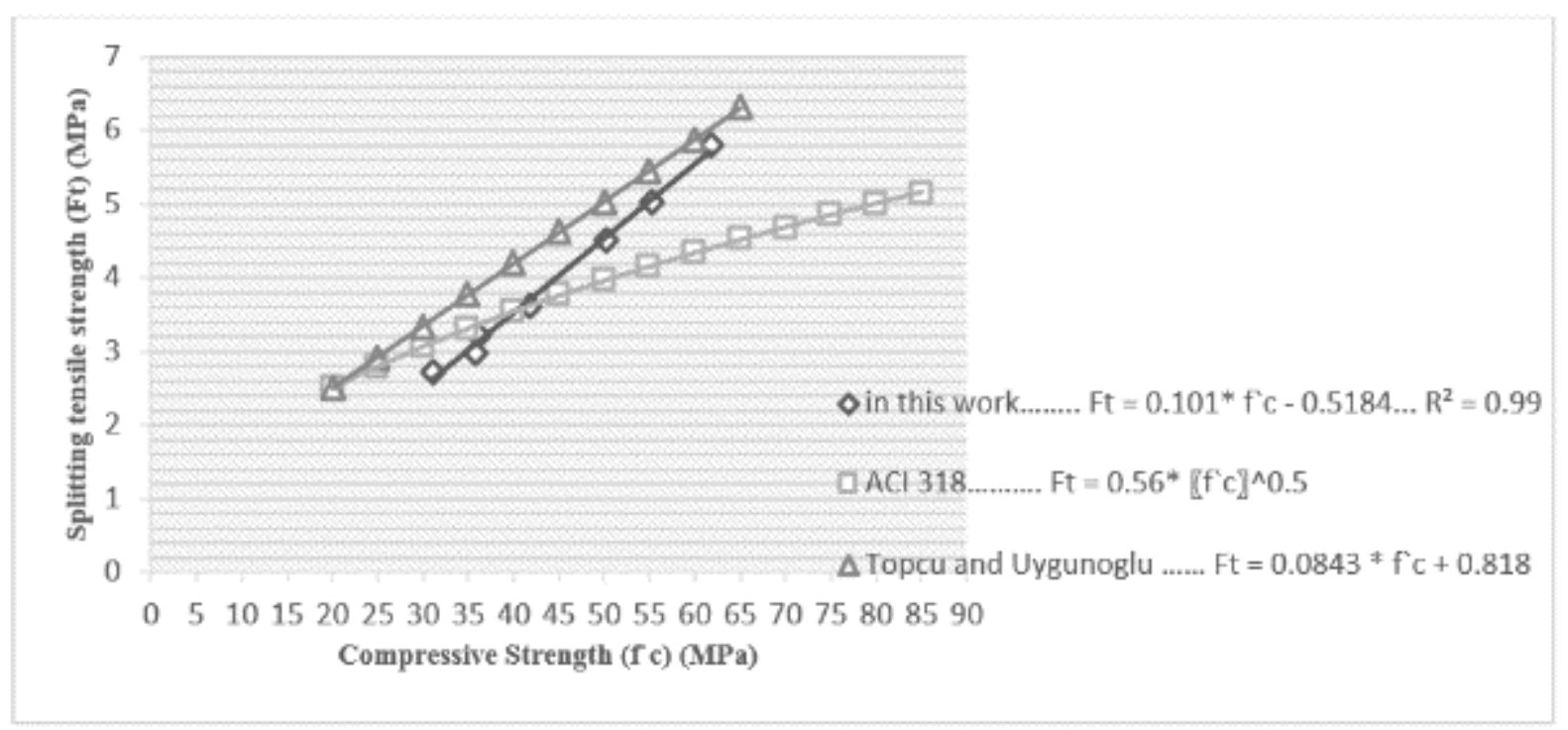

Fig. 12. The relation between splitting tensile strength and compressive strength for all mixes; ACI 318 [41] and Topcu and Uygunoglu [43]. 


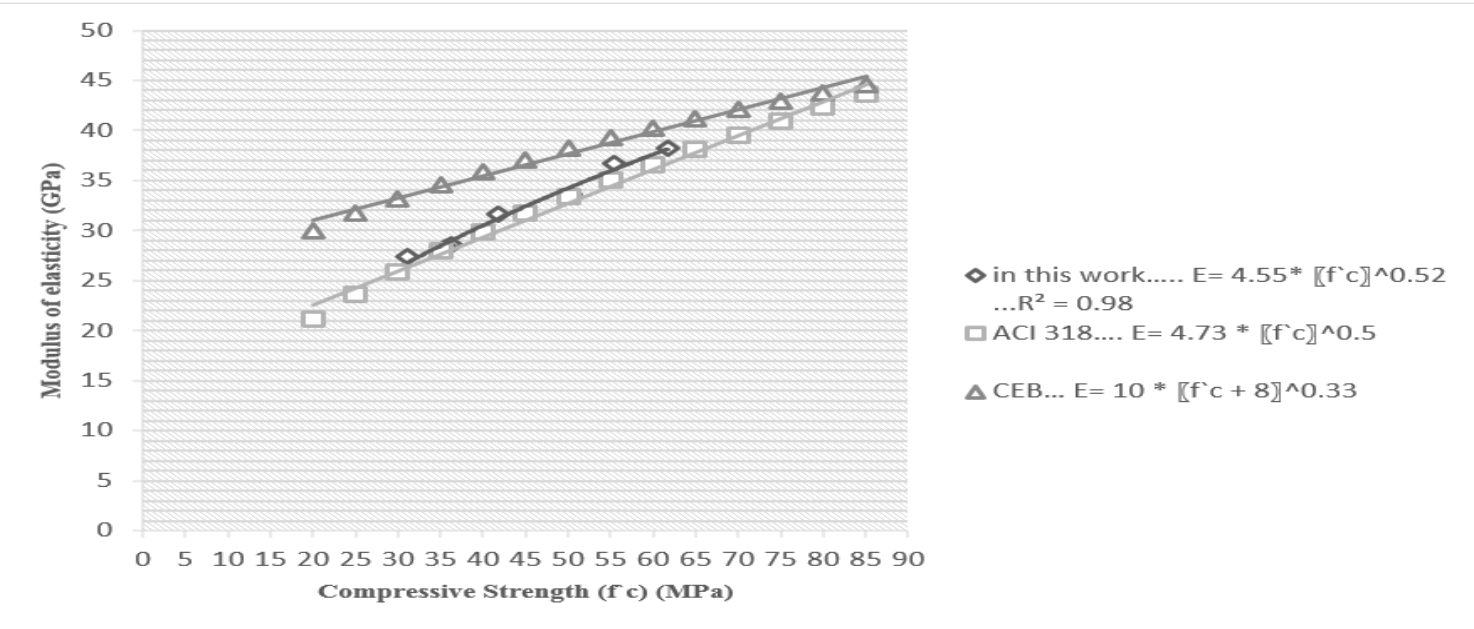

Fig. 13. The relation between modulus of elasticity and compressive strength for all mixes; ACI 318 [41] and CEB [42]

\subsection{Microstructure investigation from Scanning Electronic Microscopy (SEM)}

Fig. (14) shows microstructural characteristics from SEM imaging of the studied mixes. For REF SCC mix that contain only (PLC), the SEM images Fig. (14-a) indicated that its microstructure was uniform and compacted with low porosity. Lothenbach et al. [39] reported that high and low forms of carbo-aluminates will be formed as a result of the reaction of ground $\mathrm{CaCO}_{3}$ with various calcium aluminate hydrates during Portland cement hydration. Calcium hemi-carboaluminate generates an early hydration product in calcite containing ordinary Portland cement blends. After about 28 days, it transforms approximately entirely to calcium monocarbo-aluminate, a stable AFm phase. Thermodynamic calculations and experimental observations showed that mono-carbo-aluminate creation is preferred to mono-sulfo-aluminate. The existing sulfate reacts with water and calcium hydroxide, crystalizing as ettringite. Due to further ettringite creation, the whole volume of the hydrated phase increases, and the total porosity decreases.

For mixes containing $(40,50,60) \%$ FA Fig. (14-b, c, d) respectively, it can be seen that there are some unreacted spherical fly ash particles whereas in binary mix (50B) the amount of these particles was reduced that is an indication to the activation that happened to fly ash by cement kiln dust as discussed previously. Moreover, the formation of the hydration product "ettringite" as a needle-like shape can be recognized.

For binary mix (50B) the synergy between the inclusion materials (PLC, FA, and CKD) can produce a higher packing density that can lead to a denser microstructure as shown in Figure (14-g).

For CKD SCC mixes the SEM images, Figure (14-e, f), showed lower compacted microstructure compared to other SCC mixes and this may be due to the larger amount of chloride present in cement kiln dust causing assortment of crystallization of hydration products which result in an opening of the pore system and this confirms the reduction of strength of these mixes.

\section{Conclusions}

- Self-consolidating concrete mixtures can be produced with Portland limestone cement, highvolume class $\mathrm{F}$ fly ash, cement kiln dust and a low dosage of superplasticizers without the use of any viscosity modifying admixtures and with mechanical performance suitable for structural applications.

- One of the principal justifications of incorporating Portland limestone cements has been to enhance concrete sustainability by lowering related carbon emissions and energy usage. Although the sustainability advantages of this approach are impressive, this research investigates the premise that the PLC may also enhance concrete performance through beneficial synergies (interaction of elements that when combined exceed the sum of their individual contributions).

- Because of the unavailability of fly ash in Iraq the substitution of less-expensive CKD as a partial cement replacement improves the sustainability of SCC with reasonable strength. Where it reduces cost and environmental pollution from the disposal of CKD.

- The decreased properties during the short term of high volume fly ash concrete are effectively recovered by the incorporation of CKD and PLC (binary mix).

- When fly ash is used with CKD in binary mix, it intrinsically alleviates the higher water request of CKD (higher requirement for superplasticizers) and improve the strength.

- The replacement of cement by CKD alone lowered the compressive strength of concrete particularly with a high amount of replacement.

- A good relationship was found between hardened properties and this relationship seems 
to be unaffected by the cement replacement type and content for SCC mixes.

- The addition of fly ash resulted in a denser and uniform microstructure compared to the addition of cement kiln dust.

- Micrograph scanning showed a good agreement with mechanical test results.
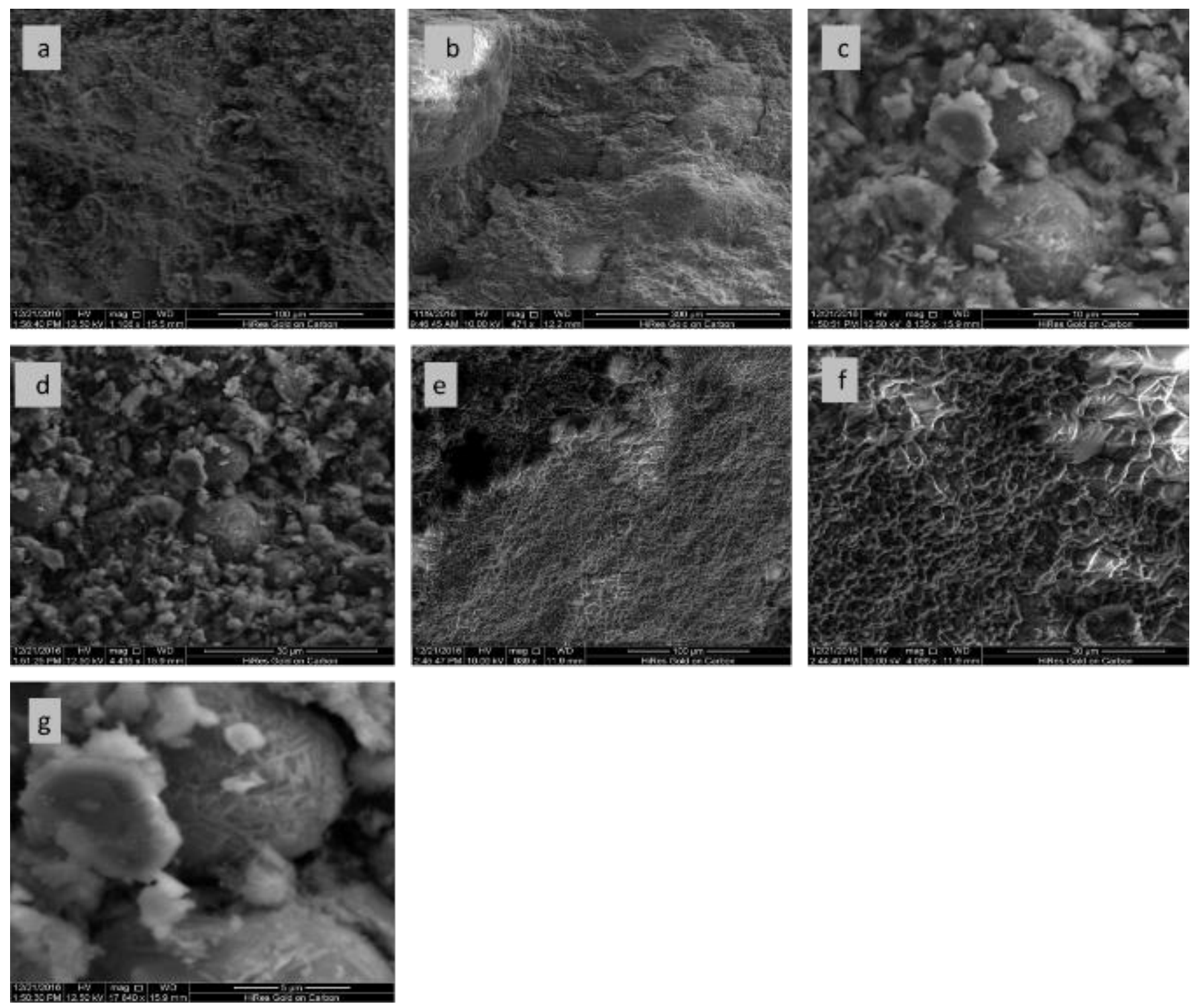

Fig. 14. SEM images for SCC mixes. (a, b, c, d, e, f, g) for (REF,40\%FA,50\%FA,60\%FA,20CKD,30CKD and 50B) respectively. 


\section{References}

[1] H. Okamura and M. Ouchi , J. of Advan Concr Tech. Vol. 1, pp. 5-15. (2003).

[2] J. Hu, I. Souza and F. Genarini, J. of Sust CemBased Mater. Vol. 6. (2016). http://dx.doi.org/10.1080/21650373.2016.1230901

[3] International Energy Agency [IEA] and World Business Council for Sustainable Development [WBCSD]. (2009). " Cement Technology Roadmap 2009 - Carbon emissions reductions up to 2050 [Online].Available: http://www.iea.org/papers/2009/Cement_Roadmap. pdf.

[4] A. Gursel, M. Eric, H. Arpad and S. Alex. Cem and Concr Comp. Vol. 51, pp.38-48. (2014)

[5] P. Pipilikaki, M. Katsioti and JL. Gallias, Const and Build Mater. Vol. 23, pp. 1042-1049. (2008) http://dx.doi.org/10.1016/j.conbuildmat.2008.05.001

[6] American Society for Testing and Materials, ASTM C595-12, "Standard specification for blended hydraulic cements ". ASTM International. (2012).

[7] European Standard, Cement - Part 1: Composition, Specifications and Conformity Criteria for Common Cements, EN 197-1, (2000).

[8] Canadian Standards Association (2008). "A3001-08: Cementitious materials for use in concrete".

[9] C. Meyer, Cem and Concr Comp. Vol. 31, pp. 601605. (2009)

[10] N. Voglis, G. Kakali, E. Chaniotakis and S. Tsivilis. Cem and Concr Comp. Vol. 27, pp. 191-196. (2005).

http://dx.doi.org/10.1016/j.cemconcomp.2004.02.006

[11] D. Hooton, M. Nokken and M. Thomas, Cement Association of Canada. (2007). www.cement.ca

[12] V. M. Malhotra and P. K. Mehta, Ottowa, Canada, Supplementary Cementing Materials for Sustainable Development. (2008).

[13] B. Mobasher, In: CBM-CI International Workshop, Karachi, Pakistan, pp. 73-90. (2008).

[14] M. Nisbet, M. Marceau and M. VanGeem, PCA R\&D Serial No. 2137a. The Portland Cement Association. (2002).

[15] X. Gao, S. Kawashima, X. Liu and P. Surendra , Cem and Concr Comp. Vol. 34, pp. 478-485. (2012).

[16] H. Dehwah, Const and Build Mater. Vol. 26, pp. 547-551. (2012).

[17] R. Kraus, T. Naik, B. Ramme and R. Kumar, Const and Build Mater. Vol. 23, pp. 3439-3442. (2009).

[18] American Society for Testing and Materials, ASTM D 5050-08, "Standard Guide for Commercial Use of Lime Kiln Dusts and Portland Cement Kiln Dusts". Annual Book of ASTM Standards (2008).

[19] P. Kunal, R. Siddique and A. Rajor, Const and Build Mater. Vol. 63, pp. 49-55. (2014).
[20] P. Domone , Cem and Concr Comp. Vol. 28, pp.197-208. (2006).

[21] EFNARC. (2005) "Specification and guidelines for self-compacting concrete ". European Federation of Producers and Applicators of Specialist Products for Structures.

[22] ACI Committee 237R-2007. "Self-Consolidating Concrete ". Farmington Hills: American Concrete Institute.

[23] Iraqi Specification, No.45/1984 "Aggregates from Natural Sources for Concrete and Construction". National Centre for Construction Laboratories and Researches, (2001).

[24] American Society for Testing and Materials, ASTM C 494-05, "Standard Specification for Chemical Admixtures for Concrete". Annual Book of ASTM Standards. (2005).

[25] American Society for Testing and Materials, ASTM C 618-05, "Standard Specification for Coal Fly Ash and Raw or Calcined Natural Pozzolan for Use in Concrete". Annual Book of ASTM Standards. (2005).

[26] B. Felekoglu, S. Turkel and B. Baradan , Bulding and Environment. Vol. 42, pp.1795-1802. (2007).

[27] W. Long, K. Khayat, G. Lemieux, S. Hwang and N. Han , MDPI, Mater J. Vol. 7, pp. 2474-2489. (2014).

[28] BS EN 12390-3. Testing hardened concrete. Compressive strength of test specimens. (2009).

[29] American Society for Testing and Materials, ASTM C 496-04,"Standard Test Method for Splitting Tensile of Cylindrical Concrete Specimens". Annual Book of ASTM Standards. (2004).

[30] H. Thanh and HM. Ludwig , Mater. and Desi. Vol.89, pp.156-166. (2015).

http://dx.doi.org/10.1016/j.matdes.2015.09.120

[31] P.K. Mehta, Proceedings of the International Workshop on Sustainable Development \& Concrete Technology. Beijing, China, pp. 3-14. (2004).

[32] ACI Committee 232.2R-03. "Use of fly ash in concrete ". Farmington Hills: American Concrete Institute. (2003).

[33] A. Leemann, R. Loser and B. Munch , Cem and Concr Comp. Vol. 32, pp.116-120. (2010). http://doi.org/10.1016/j.cemconcomp.2009.11.007

[34] H. Yazici, M. Yardimci, S. Aydin and A. Karabulut, Const. and Build. Mat. Vol. 23, pp.1223-1231. (2009). http://doi.org/10.1016/j.conbuildmat.2008.08.003

[35] K. Weerdt, M. Haha and et al. , Cem Concr Res. Vol. 41, pp. 279-291. (2011). http://doi.org/10.1016/j.cemconres.2010.11.014 
[36] R. Siddique and A. Rajor, Reso, Cons and Recy. Vol. 61, pp. 59-68. (2012). http://doi.org/10.1016/j.resconrec.2012.01.006

[37] P. Chaunsali and S. Peethamparan, ACI Mater J. Vol. 110, pp. 297-304. (2013).

[38] P.K. Mehta, and P.J. Monteiro. "Concrete: Microstructure, Properties, and Materials " Third Edition, McGraw -Hill. (2006).

[39] B. Lothenbach, G. Saout, E. Gallucci and K. Scrivener, Cem Concr Res. Vol. 38, pp. 848-860. (2008).

[40] American Society for Testing and Materials, ASTM C 469-02, " Standard Test Method for Static Modulus of Elasticity and Poisson's Ratio of Concrete in Compression " Annual Book of ASTM Standards. (2002).

[41] ACI Committee 318 "Building Code Requirements for Structural Concrete". Farmington Hills: American Concrete Institute. (2005).

[42] Euro International Committee of Concrete. CEBFIP model code 1990. London: Thomas Telford; 1993, as sited in reference [43].

[43] B. Topcu and T. Uygunoglu, Const and Build Mater. Vol. 24, pp. 1286-1295. (2010)

Table 1. Chemical and physical characteristics of Portland limestone cement (PLC) used in this study*.

\begin{tabular}{|c|c|c|c|}
\hline Oxides or Property & $\begin{array}{c}\text { PLC } \\
\text { test results }\end{array}$ & $\begin{array}{l}\text { Requirement of } \\
\text { EN 197-1 [7] }\end{array}$ & $\begin{array}{l}\text { Requirement of Iraqi industrial } \\
\text { license No: } 3868^{* *}\end{array}$ \\
\hline $\mathrm{SiO}_{2}$ & 18.8 & - & - \\
\hline $\mathrm{Al}_{2} \mathrm{O}_{3}$ & 4.8 & - & - \\
\hline $\mathrm{Fe}_{2} \mathrm{O}_{3}$ & 2.7 & - & - \\
\hline $\mathrm{CaO}$ & 61.9 & - & - \\
\hline $\mathrm{MgO}$ & 2.5 & - & $\leq 5.0 \%$ \\
\hline $\mathrm{SO}_{3}$ & 2.6 & $\leq 4.0 \%$ & $\begin{array}{l}\leq 2.5 \% \text { if } \mathrm{C}_{3} \mathrm{~A} \text { less than } 5 \% \\
\leq 2.8 \% \text { if } \mathrm{C}_{3} \mathrm{~A} \text { more than } 5 \%\end{array}$ \\
\hline $\mathrm{Na}_{2} \mathrm{O}$ & 0.2 & - & - \\
\hline $\mathrm{K}_{2} \mathrm{O}$ & 1.1 & - & - \\
\hline$\left(\mathrm{Na}_{2} \mathrm{O}\right)_{\mathrm{eq}} * * *$ & 0.92 & - & - \\
\hline L.O.I & 4.5 & - & - \\
\hline Fineness $\left(\mathrm{m}^{2} / \mathrm{Kg}\right)$ & 390 & - & - \\
\hline Initial setting time (min.) & 128 & $\geq 60.0$ & $\geq 45.0$ \\
\hline Final setting time (hr.) & 3.3 & - & - \\
\hline $\begin{array}{l}2 \text { days compressive strength } \\
(\mathrm{MPa})\end{array}$ & 23 & $\geq 20.0$ & $\geq 20.0$ \\
\hline $\begin{array}{l}\text { 28days compressive strength } \\
(\mathrm{MPa})\end{array}$ & 49 & $\geq 42.5$ & $\geq 42.5$ \\
\hline
\end{tabular}


Table 2. Grading and some physical and chemical properties of sand used.

\begin{tabular}{|c|c|c|c|}
\hline $\begin{array}{c}\text { Sieve size } \\
(\mathrm{mm})\end{array}$ & \multicolumn{2}{|c|}{ Cumulative passing \% } & $\begin{array}{c}\text { Limits of Iraqi specification } \\
\text { No.45/1984 [23], zone } 3\end{array}$ \\
\hline 4.75 & \multicolumn{2}{|c|}{97} & $90-100$ \\
\hline 2.36 & \multicolumn{2}{|c|}{89} & $85-100$ \\
\hline 1.18 & \multicolumn{2}{|c|}{75} & $75-100$ \\
\hline 0.60 & \multicolumn{2}{|c|}{60} & $60-79$ \\
\hline 0.30 & \multicolumn{2}{|c|}{22} & $12-40$ \\
\hline 0.15 & \multicolumn{2}{|c|}{5} & $0-10$ \\
\hline \multicolumn{4}{|c|}{ Fineness modulus $=2.5$} \\
\hline \multicolumn{2}{|c|}{ Property } & Test results & $\begin{array}{c}\text { Limits of Iraqi specification } \\
\text { No. } 45 / 1984[23]\end{array}$ \\
\hline \multicolumn{2}{|c|}{ Specific gravity } & 2.58 & - \\
\hline \multicolumn{2}{|c|}{ Sulfate content $\left(\mathrm{SO}_{3}\right) \%$} & 0.21 & $\leq 0.5$ \\
\hline \multicolumn{2}{|c|}{ Absorption \% } & 1.82 & - \\
\hline \multicolumn{2}{|c|}{$\begin{array}{l}\text { Materials finer than sieve No. } \\
200\end{array}$} & 1.4 & $\leq 5.0$ \\
\hline
\end{tabular}

Table 3. Grading and some physical and chemical properties of gravel used.

\begin{tabular}{|c|c|c|}
\hline Sieve size (mm) & Cumulative passing \% & $\begin{array}{c}\text { Limits of Iraqi specification } \\
\text { No. 45/1984[23] }\end{array}$ \\
\hline 37.5 & 100 & 100 \\
\hline 20 & 100 & $95-100$ \\
\hline 10 & 39 & $30-60$ \\
\hline 5 & 3 & $0-10$ \\
\hline Property & Test results & $\begin{array}{c}\text { Limits of Iraqi specification } \\
\text { No. 45/1984[23] }\end{array}$ \\
\hline Specific gravity & 2.62 & - \\
\hline Sulfate content (SO3) \% & 0.03 & $\leq 0.1$ \\
\hline Absorption $\%$ & 0.7 & - \\
\hline
\end{tabular}

Table 4. chemical analysis and physical properties of the fly ash*

\begin{tabular}{|l|c|c|}
\hline Oxides or Property & Fly ash & $\begin{array}{c}\text { ASTM C618-05[25] } \\
\text { class F requirement }\end{array}$ \\
\cline { 1 - 2 } $\mathrm{SiO}_{2}$ & 50.5 & SiO2 $+\mathrm{Al} 2 \mathrm{O} 3+\mathrm{Fe} 2 \mathrm{O} 3>70$ \\
\hline $\mathrm{Al}_{2} \mathrm{O}_{3}$ & 22.7 & \\
\hline $\mathrm{Fe}_{2} \mathrm{O}_{3}$ & 9.3 & \\
\hline $\mathrm{CaO}$ & 10.8 & - \\
\hline $\mathrm{MgO}$ & 1.2 & - \\
\hline $\mathrm{Na}_{2} \mathrm{O}$ & 1.0 & - \\
\hline $\mathrm{K}_{2} \mathrm{O}$ & 0.8 & - \\
\hline $\mathrm{TiO}_{2}$ & 0.7 & 5.0 max. \\
\hline $\mathrm{SO}_{3}$ & 1.5 & 6.0 max. \\
\hline Loss on Ignition & 1.2 & - \\
\hline Specific gravity & 2.12 & - \\
\hline Specific surface area $\left(\mathrm{m}^{2} / \mathrm{kg}\right)$ & 420 & \\
\hline * According to the supplier. & & \\
\hline
\end{tabular}


Table 5. Chemical composition and physical properties of cement kiln dust used throughout this work*

\begin{tabular}{l}
\begin{tabular}{|l|c|c|c|c|c|c|c|c|}
\hline Oxides & $\mathrm{CaO}$ & $\mathrm{SiO}_{2}$ & $\mathrm{Al}_{2} \mathrm{O}_{3}$ & $\mathrm{Fe}_{2} \mathrm{O}_{3}$ & $\mathrm{MgO}$ & $\mathrm{SO}_{3}$ & $\mathrm{Na}_{2} \mathrm{O}$ & $\mathrm{K}_{2} \mathrm{O}$ \\
\hline $\begin{array}{l}\text { Content } \\
\text { (percent) }\end{array}$ & 44.5 & 16.7 & 4.5 & 2.0 & 1.3 & 5.5 & 0.3 & 3.7 \\
\hline Property & L. O. I. & \multicolumn{2}{l}{ Fineness $\left(\mathrm{m}^{2} / \mathrm{kg}\right)$} \\
\hline
\end{tabular} \\
Test result \\
* Chemical analysis were carried out in the laboratory of $\mathrm{Al}-$ Kufa cement mill \\
\hline
\end{tabular}

Chemical analysis were carried out in the laboratory of $\mathrm{Al}$ - Kufa cement mill

Table 6. Mix proportions of the concrete mixes.

\begin{tabular}{|c|c|c|c|c|c|c|c|c|}
\hline \multirow[b]{2}{*}{ Mix ID } & \multicolumn{6}{|c|}{ Mixture proportions $\left(\mathrm{kg} / \mathrm{m}^{3}\right)$} & \multirow[b]{2}{*}{$\mathrm{W} / \mathrm{P}^{*}$} & \multirow[b]{2}{*}{$\mathrm{SP}^{* *}$} \\
\hline & Cement & Fly ash & $\begin{array}{l}\text { Cement } \\
\text { kiln dust }\end{array}$ & Water & Sand & Gravel & & \\
\hline REF & 500 & - & - & 180 & 800 & 800 & 0.36 & 0.8 \\
\hline 40FA & 300 & 200 & - & 180 & 800 & 800 & 0.36 & 0.7 \\
\hline $50 \mathrm{FA}$ & 250 & 250 & - & 180 & 800 & 800 & 0.36 & 0.6 \\
\hline 60FA & 200 & 300 & - & 180 & 800 & 800 & 0.36 & 0.55 \\
\hline 20CKD & 400 & - & 100 & 180 & 800 & 800 & 0.36 & 0.9 \\
\hline $30 \mathrm{CKD}$ & 350 & - & 150 & 180 & 800 & 800 & 0.36 & 1.1 \\
\hline $50 \mathrm{~B}$ & 250 & 150 & 100 & 180 & 800 & 800 & 0.36 & 0.9 \\
\hline
\end{tabular}

* W/P : water / powder : water / (cement + FA +CKD)

** $\mathrm{Sp}$ : superplasticizer : (Lit/100Kg cementitious material)

Table 7. Fresh properties of SCC mixes

\begin{tabular}{|c|c|c|c|c|c|c|c|}
\hline \multirow{2}{*}{\multicolumn{2}{|c|}{ Mix ID }} & \multicolumn{2}{|c|}{ Filling ability } & \multicolumn{3}{|c|}{ Passing ability (J-ring test) } & \multirow{2}{*}{$\begin{array}{l}\text { Segregation } \\
\text { resistance \% }\end{array}$} \\
\hline & & $\begin{array}{c}\text { Slump } \\
\text { flow }\left(\mathrm{d}_{\mathrm{s}}\right) \\
\mathrm{mm}\end{array}$ & Spread time $\left(\mathrm{T}_{50}\right) \mathrm{S}$. & $\begin{array}{l}\text { Differences in } \\
\text { heights }(\mathrm{mm})\end{array}$ & $\begin{array}{l}\text { Flow } \\
\left(\mathrm{d}_{\mathrm{j}}\right)\end{array}$ & $\left(d_{s}-d_{j}\right)$ & \\
\hline \multicolumn{2}{|c|}{ REF } & 695 & 2 & 3.7 & 676 & 19 & 7.2 \\
\hline \multicolumn{2}{|c|}{ 40FA } & 727 & 2.3 & 3.1 & 709 & 18 & 5 \\
\hline \multicolumn{2}{|c|}{ 50FA } & 740 & 2.7 & 2.8 & 725 & 15 & 4.8 \\
\hline \multicolumn{2}{|c|}{ 60FA } & 752 & 3 & 2 & 738 & 14 & 4.5 \\
\hline \multicolumn{2}{|c|}{ 20CKD } & 680 & 3.8 & 5 & 655 & 25 & 3 \\
\hline \multicolumn{2}{|c|}{ 30CKD } & 668 & 4.5 & 6.3 & 630 & 38 & 2.5 \\
\hline \multicolumn{2}{|c|}{$50 \mathrm{~B}$} & 700 & 3 & 4.1 & 679 & 21 & 3.5 \\
\hline \multirow{2}{*}{  } & 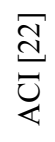 & $\begin{array}{l}8 \\
8 \\
1 \\
0 \\
7 \\
7\end{array}$ & $\begin{array}{l}n \\
1 \\
\sim\end{array}$ & ' & & $\begin{array}{l}2 \\
1 \\
1 \\
0\end{array}$ & $\begin{array}{l}0 \\
1 \\
0\end{array}$ \\
\hline & 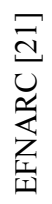 & $\begin{array}{l}0 \\
\infty \\
1 \\
1 \\
n \\
n\end{array}$ & $\begin{array}{l}n \\
i \\
i\end{array}$ & $\begin{array}{c}0 \\
1 \\
1 \\
0\end{array}$ & & ' & ' \\
\hline
\end{tabular}


Table 8. Hardened properties of SCC mixes

\begin{tabular}{|l|c|c|c|c|c|c|c|c|}
\hline \multirow{2}{*}{ Mix ID } & \multicolumn{4}{|c|}{ Compressive strength (MPa) } & \multicolumn{2}{c|}{$\begin{array}{c}\text { Splitting tensile strength } \\
(\mathrm{Mpa})\end{array}$} & \multicolumn{2}{c|}{$\begin{array}{c}\text { Modulus of elasticity } \\
(\mathrm{GPa})\end{array}$} \\
\cline { 2 - 10 } & 7 days & 28 days & 56 days & 90 days & 28 days & 90 days & 28 days & 90 days \\
\hline REF & 42.1 & 61.7 & 63.8 & 66.2 & 5.80 & 6.12 & 38.24 & 41.15 \\
\hline 40FA & 36.4 & 50.2 & 58.7 & 61.1 & 4.51 & 5.44 & 33.58 & 35.52 \\
\hline 50FA & 32.3 & 41.8 & 52.7 & 56.3 & 3.62 & 4.71 & 31.60 & 35.11 \\
\hline 60FA & 28.7 & 36.2 & 45.3 & 50.1 & 3.21 & 4.42 & 28.52 & 34.24 \\
\hline 20CKD & 30.6 & 35.7 & 36.8 & 38.1 & 3.00 & 3.4 & 28.30 & 31.22 \\
\hline 30CKD & 25.2 & 31.1 & 33.4 & 34.7 & 2.71 & 2.90 & 27.41 & 29.60 \\
\hline 50B & 38.0 & 55.4 & 60.6 & 64.8 & 5.03 & 5.71 & 36.74 & 39.85 \\
\hline
\end{tabular}

